\title{
SISTEM PAKAR DIAGNOSA JENIS-JENIS PENYAKIT DEMAM PANAS PADA BALITA DENGAN MENGGUNAKAN METODE FUZZY LOGIC BERBASIS WEB
}

\author{
M. Irwan Ukkas ${ }^{1)}$, Shinta Palupi ${ }^{2)}$, Inka Pradiba ${ }^{3)}$ \\ ${ }^{1,2}$ Sistem Informasi, STMIK Widya Cipta Dharma \\ ${ }^{3}$ Teknik Informatika, STMIK Widya Cipta Dharma \\ ${ }_{1,2,3}$ Jl. Prof. M. Yamin No. 25, Samarinda, 75123 \\ E-mail : Irwan212@yahoo.com ${ }^{1)}$, caca_200177@gmail.com ${ }^{2)}$, inkha.pradiba92@gmail.com ${ }^{3)}$
}

\begin{abstract}
ABSTRAK
Selama ini sudah ada beberapa metode dalam melakukan diagnosa penyakit, terutama dalam bentuk sistem pakar. Pada tugas akhir ini, akan digunakan fuzzy inference sistem dengan metode Tsukamoto untuk menentukan jenis-jenis penyakit demam panas yang mungkin diderita oleh pasien. Input yang dibutuhkan adalah gejala-gejala yang dialami oleh pasien. Basis pengetahuan dibangun dengan menggunakan kaidah produksi (IF-THEN). $\alpha$-predikat (Fire strength) yang diperoleh pada setiap aturan fuzzy untuk setiap penyakit pada basis pengetahuan, kemudian dikomposisikan dengan menggunakan rata-rata terbobot. Hasil rata-rata terbobot ini merupakan output tingkat resiko penyakit.
\end{abstract}

Dengan Menerapkan metode diatas, maka lebih dihasilkan sebuah sistem pakar diagnosa jenis-jenis penyakit demam panas yang dapat memberikan kemudahan kepada masyarakat untuk mendapatkan informasi tentang gejala-gejala penyakit demam panas. Sistem ini juga dapat membantu kinerja pakar yaitu dengan mudah menambah, mengganti dan menghapus data (pengetahuannya).

Kata Kunci : Sistem Infrensi Fuzzy, Metode Tsukamoto, Penyakit Demam Panas

\section{PENDAHULUAN}

Sejalan dengan berkembangnya teknologi maka dikembangkan pula suatu aplikasi atau software pendukung yang mampu mengadopsi proses dan cara berpikir manusia yaitu teknologi Artificial Intelligent atau Kecerdasan Buatan. Sistem Pakar adalah suatu bagian dari Kecerdasan Buatan yang mengandung pengetahuan dan pengalaman yang dimasukkan oleh satu atau banyak ke dalam satu area pengetahuan tertentu sehingga setiap orang dapat menggunakannya untuk memecahkan berbagai masalah yang bersifat spesifik, dalam hal ini adalah permasalahan kesehatan anak pada manusia.

Penyampaian informasi pun dilakukan melalui dunia maya (internet). Dengan menggunakan Website diharapkan penerapan sistem pakar untuk mendiagnosa penyakit demam panas pada balita, akan banyak manfaat dan mampu memberikan informasi yang optimal.

Pada masa sekarang masyarakat awam khususnya para ibu masih sering mengalami kesulitan untuk mendiagnosis jenis penyakit demam panas karena keterbatasan pengetahuan yang mereka miliki. Sedangkan untuk menemui ahli atau pakar dalam bidang tersebut dirasa cukup sulit. Oleh sebab itu, diperlukan suatu aplikasi sistem yang dapat menampung pengetahuan dari seorang pakar dan dapat mendiagnosis jenis penyakit demam panas serta tindakan yang dapat dilakukan untuk menanggulanginya. Namum, terkadang pelayanan kesehatan tidak bisa semuanya menyentuh lapisan masyarakat dikarenakan tempat yang terlalu jauh dari pusat kesehatan dan biaya yang tidak sedikit yang harus dikeluarkan untuk mendapatkan pelayanan kesehatan, dan minimnya para ahli, untuk itu diperlukan suatu teknologi yang dapat membantu mendiagnosa penyakit demam panas pada balita.

\section{RUANG LINGKUP PENELITIAN}

Berikut dijabarkan ruang lingkup dari penelitian:

1. User dapat berkonsultasi tentang penyakit demam panas melalui web ini.

2. Admin dapat menginputkan gejala penyakit disertai dengan perhitungan fuzzynya secara dinamis.

3. Fungsi keanggotaan yang digunakan adalah linear naik, linear turun dan kurva segitiga.

4. Representasi pengetahuan yang digunakan adalah sistem pakar berbasis Rule dan dalam penalaran menggunakan Logika Fuzzy metode Tsukamoto dalam melakukan Inference sistem.

5. Metode defuzzyfikasi yang digunakan adalah rata-rata berbobot.

6. Dalam penelitian ini hanya dibatasi membahas jenisjenis penyakit demam panas dan cara penanganannya serta pencegahannya secara dini pada balita serta penulis hanya membatasi 5 (lima) jenis penyakit yaitu : demam berdarah, demam malaria, campak, demam tipoid dan gejala meningitis.

7. Output berupa identifikasi kemungkinan jenis penyakit demam panas yang menyerang user atau 
pasien serta nilai presentasi terhadap jenis penyakit demam panas.

8. Output tidak menampilkan proses perhitungan detail dari analisis fuzzy logic dalam menentukan suatu penyakit yang diderita oleh user.

\section{BAHAN DAN METODE}

\subsection{Kecerdasan Buatan}

Menurut Kristanto (2004), Kecerdasan buatan merupakan bagian dari ilmu pengetahuan komputer yang khusus ditujukan dalam perancangan otomatisasi tingkah laku cerdas dalam sistem kecerdasan komputer. Sistem memperlihatkan sifat-sifat khas yang dihubungkan dengan kecerdasan dalam kelakuan atau tindak-tanduk yang sepenuhnya bisa menirukan beberapa fungsi otak manusia, seperti pengertian bahasa, pengetahuan, pemikiran, pemecahan masalah dan lain sebagainya.

\subsection{Sistem}

Menurut Kadir (2003), pada dasarnya sistem adalah sekumpulan elemen yang saling terkait atau terpadu yang dimaksudkan untuk mencapai suatu tujuan.

\subsection{Pakar}

Menurut Arhami (2005), pakar adalah orang yang mempunyai keahlian dalam bidang tertentu, yaitu pakar yang mempunyai knowlegde atau kemampuan khusus yang orang lain tidak mengetahui atau mampu dalam bidang yang dimilikinya

\subsection{Sistem Pakar}

Sistem pakar (expert system) adalah sistem berbasis komputer yang menggunakan pengetahuan, fakta, dan teknik penalaran dalam memecahkan masalah yang biasanya hanya dapat dipecahkan oleh seorang pakar dalam bidang tersebut. Pada dasarnya sistem pakar diterapkan untuk mendukung aktivitas pemecahan masalah.

Ciri-ciri sistem pakar adalah sebagai berikut :

1. Terbatas pada bidang yang spesifik

2. Dapat memberikan penalaran untuk data-data yang tidak lengkap atau tidak pasti.

3. Dapat mengemukakan rangkaian alasan diberikan dengan cara yang dapat dipahami

4. Berdasarkan pada rule atau kaidah tertentu

5. Dirancang untuk dikembangkan secara bertahap

6. Outputnya bersifat nasihat atau anjuran

7. Output tergantung dari dialog dengan user

8. Knowledge base dan interface engine terpisah.

\subsection{Logika Fuzzy}

Pernyataan-pernyataan "sangat fleksibel", "lumayan pendek", penyelesaian yang bagus" adalah pernyataan yang ambigu. Pernyataan ambigu merupakan karakteristik manusia berkomunikasi secara linguistik dan itu adalah bagian yang terintegrasi dengan proses berfikir. Hal tersebut sangat berbeda dari pemrograman komputer dengan logika boolean yang hanya menyatakan benar dan salah. Logika fuzzy dapat menjembatani perbedaan boolean dengan hal yang ambigu. Logika fuzzy menyediakan suatu cara untuk merubah pernyataan linguistik menjadi suatu numerik. Logika fuzzy adalah suatu cara yang tepat untuk memetakan suatu ruang input $\mathrm{k}\left[{ }^{\circ} \mathrm{e}\right.$ dalam suatu ruang output (Kusumadewi dan Purnomo, 2004).

\subsection{Himpunan Fuzzy}

Himpunan crisp A didefinisikan oleh elemenelemen yang ada pada himpunan itu. Jika a€A maka a bernilai 1. Jika a€A maka a bernilai 0. Himpunan fuzzy didasarkan pada gagasan untuk memperluas jangkauan fungsi karakteristik pada himpunan crisp sedemikian sehingga fungsi tersebut mencakup bilangan real pada interval $[0,1]$. jika $X$ adalah kumpulan objek yang dinotasikan $\mathrm{x}$ maka himpunan fuzzy A dalam X adalah himpunan pasangan berurutan :

$$
A=\left\{\left(x, \mu_{A}(x)\right) \mid x \in X\right\}
$$

dengan $\mu_{\mathrm{A}}(\mathrm{x})$ adalah derajat keanggotaan dari $\mathrm{x}$. Himpunan fuzzy A dalam semesta pembicaraan $\mathrm{K}$ ialah kelas kejadian (class of events) dengan fungsi keanggotaan $\mu_{\mathrm{A}}(\mathrm{x})$ kontinu yang dihubungkan dengan setiap titik dalam $\mathrm{K}$ oleh bilangan real dalam interval [0,1] dengan nilai $\mu_{\mathrm{A}}(\mathrm{x})$ pada $\mathrm{x}$ menyatakan derajat keanggotaan $\mathrm{x}$ dalam $\mathrm{A}$.

Semesta pembicaraan adalah keseluruhan nilai yang diperbolehkan untuk di operasikan dalam suatu variabel fuzzy (Kusumadewi dan Hartati, 2010). Domain himpunan fuzzy adalah keseluruhan nilai yang diijinkan dalam semesta pembicaraan dan boleh dioperasikan dalam suatu himpunan fuzzy (Kusumadewi dan Hartati, 2010).

Himpunan fuzzy memiliki dua atribut, yaitu linguistik dan numerik. Linguistik merupakan penamaan suatu grup yang mewakili suatu keadaan atau kondisi tertentu dengan menggunakan bahasa alami, seperti tinggi, rendah, besar dan bagus. Numerik adalah suatu nilai atau angka yang menunjukkan ukuran dari suatu variabel, seperti 40, 120 dan 325 (Kusumadewi dan Hartati, 2010).

\subsection{Fungsi Derajat Keanggotaan Fuzzy}

Fungsi keanggotaan adalah suatu kurva yang menunjukkan pemetaan titik-titik input data ke dalam nilai keanggotaan yang memiliki nilai interval antara 0 dan 1. Salah satu cara yang digunakan untuk mendapatkan nilai keanggotaan adalah dengan melalui pendekatan fungsi. Ada beberapa pendekatan fungsi yang dapat digunakan yaitu :

1. Representasi Linier

Salah satu representasi fungsi keanggotaan dalam fuzzy yang akan dipakai adalah representasi linier. Pada representasi linier, pemetaan input ke derajat keanggotaanya digambarkan sebagai suatu garis lurus. Gambar grafik fungsi keanggotaannya adalah : 


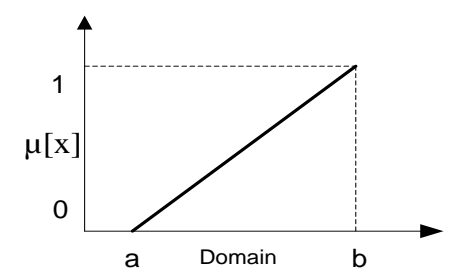

Gambar 1 Representasi Linier Naik

Fungsi keanggotaan linier naik adalah :

$$
\mu[\mathrm{x}]= \begin{cases}0 ; & \mathrm{x} \leq \mathrm{a} \\ (\mathrm{x}-\mathrm{a}) /(\mathrm{b}-\mathrm{a}) ; & \mathrm{a} \leq \mathrm{x} \leq \mathrm{b} \\ 1 ; & \mathrm{x} \geq \mathrm{b}\end{cases}
$$

Kedua, merupakan kebalikan yang pertama. Garis lurus dimulai dari nilai domain dengan derajat keanggotaan tertinggi pada sisi kiri, kemudian bergerak menurun ke nilai domain yang memiliki derajat keanggotaan lebih rendah. Gambar grafik fungsi keanggotaannya adalah :

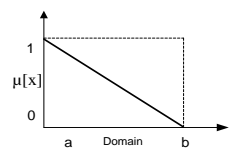

Gambar 2 Representasi Linier Turun

Fungsi keanggotaan linier turun adalah :

$$
\mu[\mathrm{x}]= \begin{cases}(\mathrm{b}-\mathrm{x}) /(\mathrm{b}-\mathrm{a}) & \mathrm{a} \leq \mathrm{x} \leq \mathrm{b} \\ 0 ; & \mathrm{x} \geq \mathrm{b}\end{cases}
$$

2. Representasi Kurva Segitiga

Kurva segitiga pada dasarnya merupakan gabungan antara 2 garis (linier) seperti pada gambar 2.4 berikut ini :

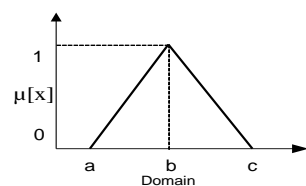

Gambar 3 Representasi Kurva Segitiga

Fungsi keanggotaan kurva segitiga dinyatakan dengan :

$$
\mu[x]= \begin{cases}0 ; & x \leq a \text { atau } x \geq c \\ (x-a) /(b-a) ; & a \leq x \leq b \\ (c-x) /(c-b) ; & b \leq x \leq c\end{cases}
$$

\subsection{Operator Dasar Zadeh Untuk Operasi Himpunan Fuzzy}

Menurut Kusumadewi dan Purnomo (2010), seperti halnya himpunan konvensional, ada beberapa operasi yang didefinisikan secara khusus untuk mengkombinasi dan memodifikasi himpunan fuzzy. Nilai keanggotaan sebagai hasil dari operasi 2 himpunan sering dikenal dengan nama fire strength atau $\alpha$-predikat. Ada 3 operator dasar yang diciptakan oleh Zadeh, yaitu :

1. Operator AND

Operator ini berhubungan dengan operasi interaksi pada himpunan $\alpha$-predikat sebagai hasil operasi dengan operator AND diperoleh dengan mengambil nilai keanggotaan terkecil antar elemen pada himpunan-himpunan yang bersangkutan.

2. Operator OR

$$
\mu A \cap B=\min (\mu \mathrm{A}[\mathrm{x}], \mu \mathrm{B}[\mathrm{y}])
$$

Operator ini berhubungan dengan operasi union (gabungan) pada himpunan $\alpha$-predikat sebagai hasil operasi dengan operator OR diperoleh dengan mengambil nilai keanggotaan terbesar antar elemen pada himpunan-himpunan yang bersangkutan.

$$
\mu A \cup B=\max (\mu A[\mathrm{x}], \mu \mathrm{B}[\mathrm{y}])
$$

3. Operator NOT

Operator ini berhubungan dengan operasi komplemen pada himpunan $\alpha$-predikat sebagai hasil operasi dengan operator NOT diperoleh dengan mengurangkan nilai keanggotaan elemen pada himpunan yang bersangkutan dari 1 .

\subsection{MetodeTsukamoto}

Menurut Kusumadewi dan Purnomo (2010), metode Tsukamoto merupakan perluasan dari penalaran monoton. pada metode Tsukamoto, setiap konsekuen pada aturan yang berbentuk IF-THEN harus direpresentasikan dengan suatu himpunan fuzzy dengan fungsi keanggotaan yang monoton. Sebagai hasilnya, output hasil inferensi dari tiap-tiap aturan diberikan secara tegas (crisp) berdasarkan $\alpha$-predikat (fire strength). Hasil akhirnya diperoleh dengan menggunakan rata-rata berbobot.

\subsection{Diagnosa}

Diagnosa adalah identifikasi mengenai sesuatu yang digunakan dalam medis, ilmu pengetahuan, teknik, bisnis, dan lainnya.

\section{Penyakit Demam Panas}

Menurut Erinika (2007), bahwa berdasarkan jenisnya, Demam Panas dapat diklasifikaikan dan diambil tindakan. Adapun jenis penyakit demam panas adalah sebagai berikut :

1. Demam Tipoid

2. Campak

3. Difteri

4. Neurologi kejang demam

5. Meningitis

\section{RANCANGAN SISTEM/ APLIKASI}

Pada bagian ini memperlihatkan urutan proses dalam sistem yang menunjukkan alat media input, output serta jenis media penyimpanan dalam proses flowchart. 


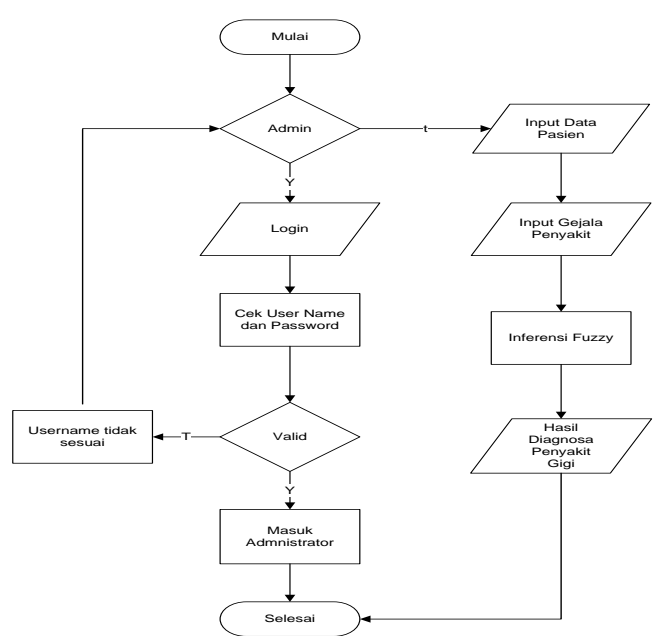

Gambar 4 Flowchart Sistem

Pada gambar 4 menjelaskan proses jalannya program. Dimulai dari pilihan, jika memilih masuk admin, maka melakukan login terlebih dahulu dengan masukkan username dan password, jika benar maka akan masuk ke halaman asministrator, jika salah input login username dan password. Selanjutnya jika memilih masuk sebagai user maka melakukan konsultasi dimulai dari input data pasien menginputkan gejala yang diderita, keproses mesin inferensi fuzzy sampai menghasilkan hasil diagnosa.

\section{Flowchart Penelusuran} Flowchart User

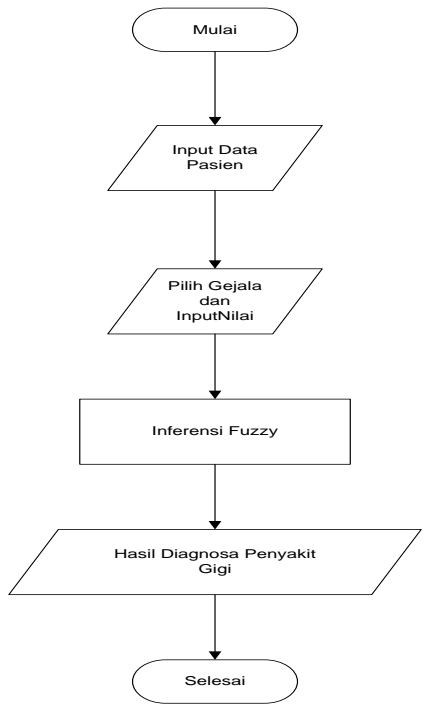

\section{Gambar 5 Flowchart User}

\section{IMPLEMENTASI}

\subsection{Halaman Menu Utama}

- Pada tampilan beranda ini terdapat beberapa menu yaitu menu beranda, menu buku yang digunakan kalau pengunjung ingin memberikan komentar,menu konsultasi yaitu menu yang menampilkan tabel konsultasi user atau pasien untuk melakukan konsultasi yang sebelumnya user atau pasien mengisi daftar pasien, menu berita yaitu menu yang menampilkan suatu berita tentang seputar penyakit gigi dan berita-berita lainnya. Berikut ini adalah tampilan beranda pada website ini.

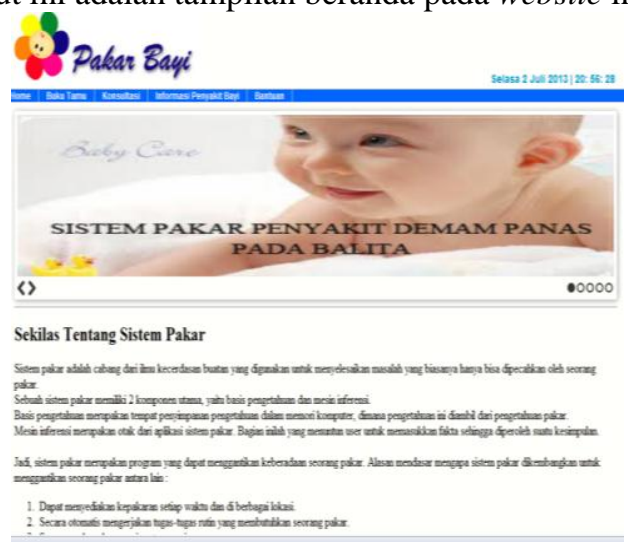

Gambar 6. Form Menu Utama

\subsection{Halaman Buku Tamu}

Pada tampilan buku tamu disediakan untuk pengunjung atau user memberikan komentar atau pertanyaan tentang website ini yang, nantinya admin akan menjawab pertanyaan-pertanyan yang ditanyakan useratau pengunjung Berikut ini tampilan dari buku tamu.

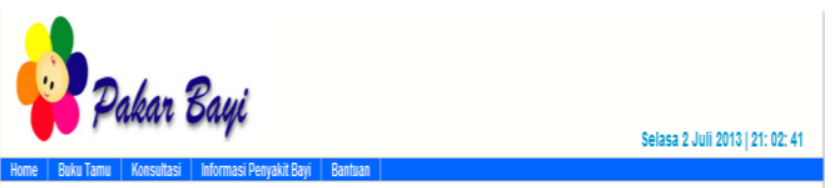

\section{Isi Data Anda}

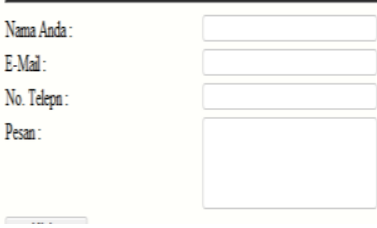

\section{Gambar 7 Form Buku Tamu}

\subsection{Halaman Input Data Pasien}

Pada halaman ini sebelum melakukan konsultasi pasien atau user terlebih dahulu mengisi data pasien . Berikut adalah tampilan halaman penginputan data pasien :

\section{Palear Bayi}

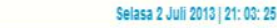

Input Data Bayi

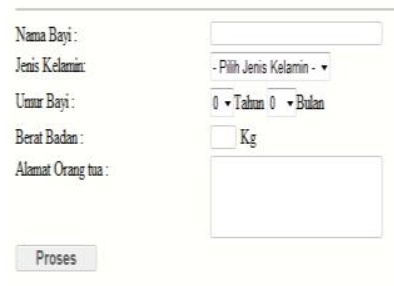

Gambar 8 Form Input Data Pasien 


\subsection{Halaman Menu Konsultasi}

Pada halaman ini pasien atau user akan bisa megetahui panyakit gigi jenis apa yang kira-kira diderita pasien, seberapa persen penyakit itu serta bisa mengetahui solusi yang disarankan oleh sistem kepada pasien. Berikutini adalah tampilan halaman hasil konsultasi

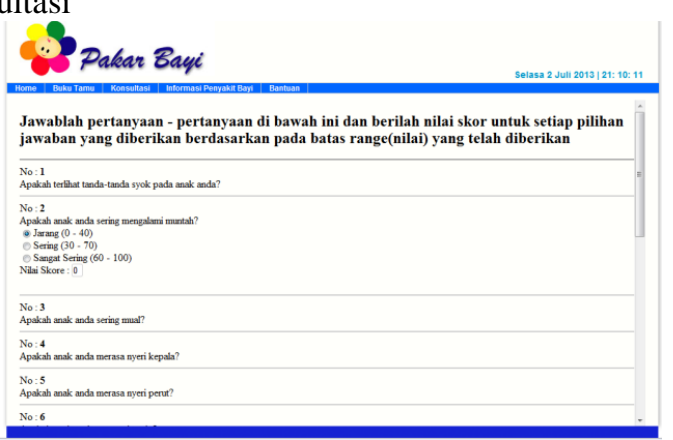

Gambar 9 Form Input Konsultasi

\subsection{Halaman Login Administrator}

Berikut tampilan login admin sebelum masuk halaman administrator

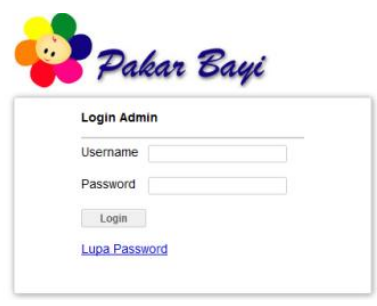

\section{Gambar 10 Form Login Administrator}

\subsection{Halaman Menu Administrator}

Pada tampilan halaman ini menampilkan menu administrator. Berikut ini tampilan darihalaman depan administrator.

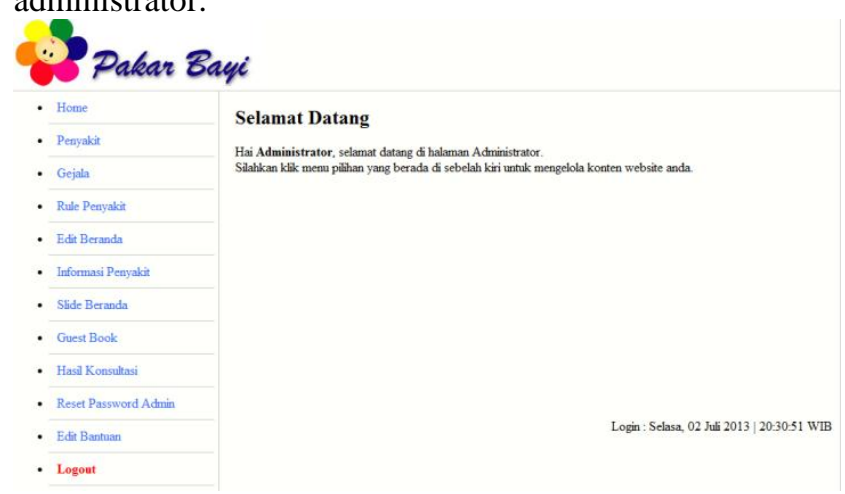

\section{Gambar 11 Form Menu Administrator}

\subsection{Halaman Administrator Informasi Penyakit}

Pada tampilan halaman berita ini admin biasa menambah berita, mengedit informasi penyakit serta menghapus informasi. Berikut ini tampilannya:

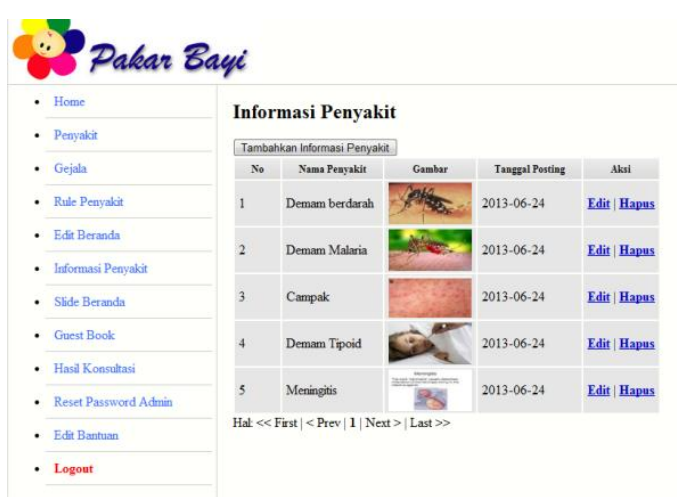

Gambar 12 Form Administrator Informasi Penyakit

5.8 Halaman Administrator Penyakit

Pada halaman ini menampilkan halamn penyakit, dimana dari halaman ini admin bisa menambah jenis penyakit, mengedit data, serta menghapus data. Berikut tampilan dari halan penyakit:

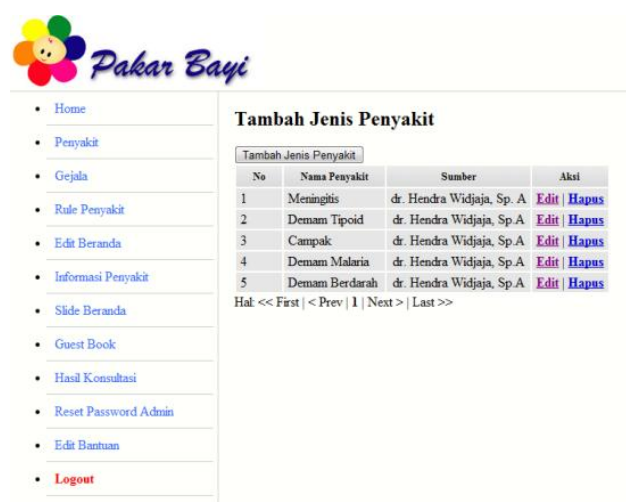

Gambar 13 Form Administrator Penyakit

\subsection{Halaman Administrator Gejala}

Pada halaman ini menampilkan gejala-gejala penyakit yang ada, admin bisa menambah data gejala, dimana melalui halaman ini admin bisa mengedit, serta menghapus gejala. Berikut ini tampila halaman gejala penyakit :

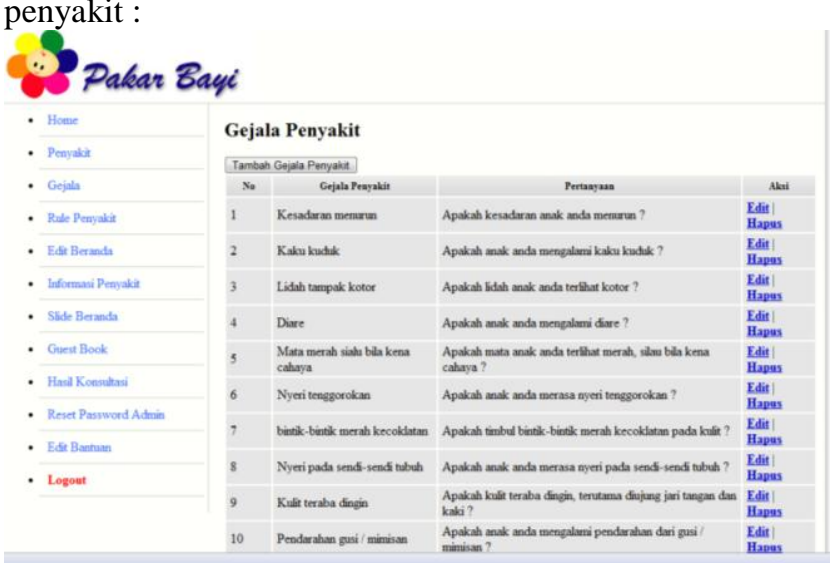

Gambar 14 Form Administrator Gejala

\section{Halaman Administrator Rule}

Pada halaman ini menampilkan Rule dari tiap tiap penyakit dan gejala penyakit pada administrator. Dimana dari halaman ini admin menambah Rule. Berikut tampilan halaman Rule : 


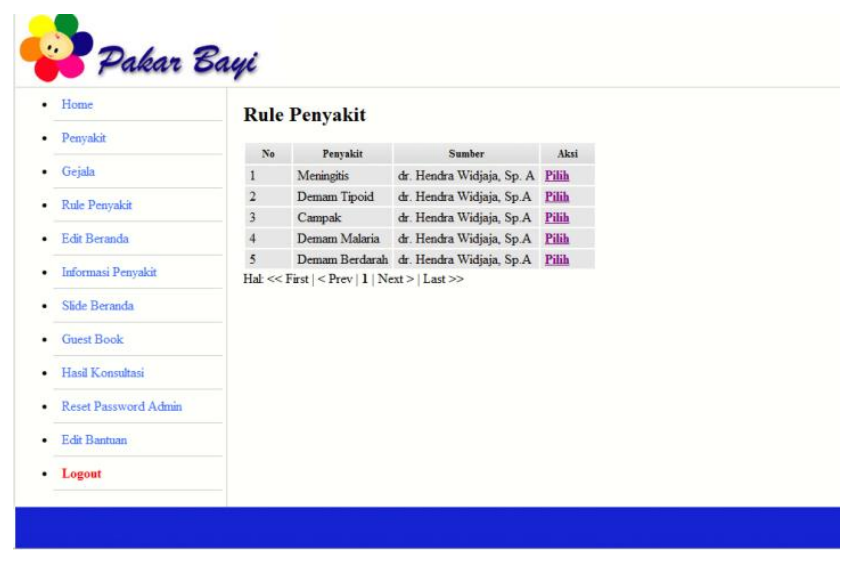

Gambar 15 Form Admnistrator Rule

\section{Halaman Adminstrator Pasien}

Pada halaman ini menampilkan biodata pasien yang telah melakukan konsultasi penyakit gigi pada administrator. Pada halaman ini admin bisa menghapus data pasien Berikut ini tampilan halaman pasien pada administrator :

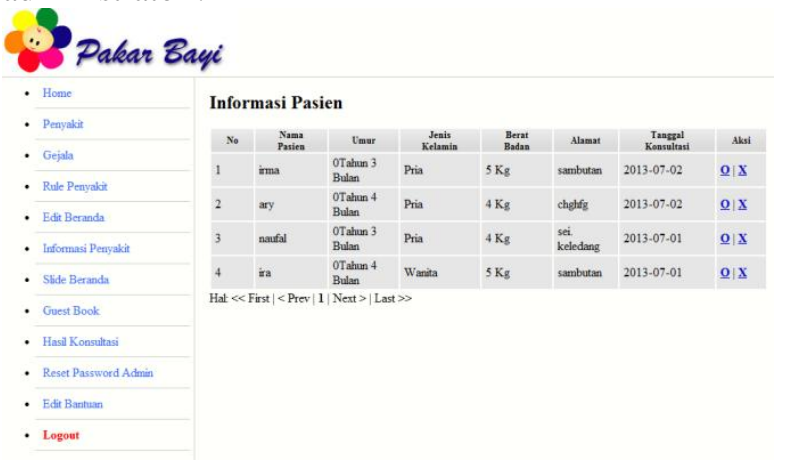

Gambar 16 Form Admnistrator Pasien

\section{Halaman Administrator Buku Tamu}

Pada Halaman ini menampilkan data buku tamu yang berisi data pengunjung yang memberikan komentar, masukan dan pertanyaan dimana nanti admin bisa menjawab pertanyaan dari halaman ini. Pada halaman ini admin juga bisa menghapus data. Berikut tampilan halaman buku tamu :

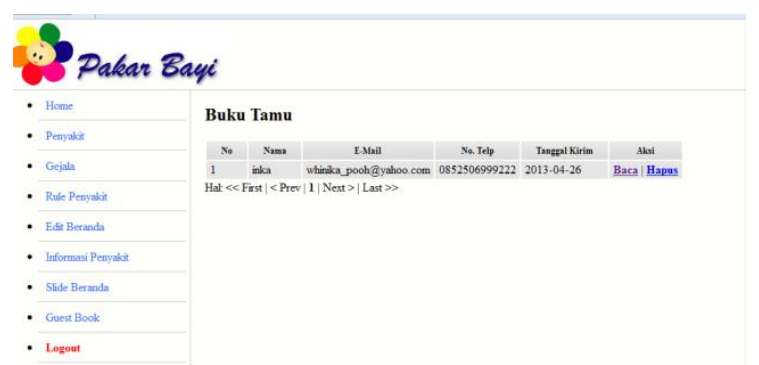

Gambar 17 Form Admnistrator Buku Tamu

\section{Halaman Hasil Konsultasi}

Pada halaman ini pasien atau user akan bisa megetahui panyakit gigi jenis apa yang kira-kira diderita pasien, seberapa persen penyakit itu serta bisa mengetahui solusi yang disarankan oleh sistem kepada pasien. Berikut ini adalah tampilan halaman hasil konsultasi

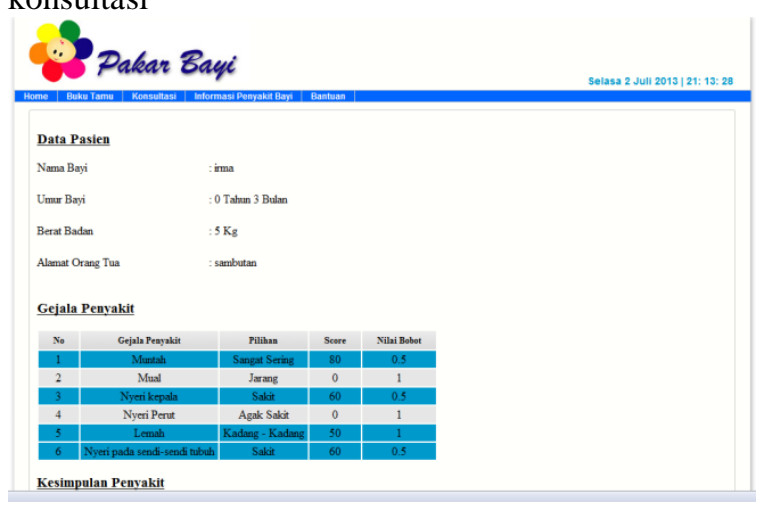

\section{Gambar 18 Form Hasil Konsultasi}

\section{KESIMPULAN}

1. Aplikasi sistem pakar diagnosa penyakit demam panas pada balita dengan menggunakan metode logika fuzzy ini dibuat sebagai alat bantu untuk menentukan resiko terbesar penyakit demam panas yang diderita berdasarkan gejala-gejala fisik yang di rasakan dengan menggunakan fuzzy Tsukamoto.

2. Masyarakat awam dapat memanfaatkan sistem ini dengan mudah untuk mengetahui kemungkinan penyakit demam panas yang diderita oleh balita.

3. Dengan sistem yang telah dibuat mampu mendiagnosa penyakit demam panas pada balita dengan dilengkapi nilai defuzzyfikasi untuk menentukan rata-rata terbobot dari penyakit demam panas pada balita

\section{SARAN}

1. Sistem pakar diagnosa penyakit demam panas pada balita dengan menggunakan metode logika fuzzy untuk menentukan jenis penyakit demam panas pada balita ini masih berupa program sederhana, yang masih bisa dikembangkan lagi untuk mencapai keakuratan data.

2. Diharapkan sistem pakar ini dapat dikembangkan lebih lanjut, dengan menambahkan output detail perhitungan dari analisis fuzzy logicnya beserta grafik sehingga user dapat mengetahui bagaimana perhitungan fuzzy logic dalam menentukan suatu penyakit.

3. Dengan adanya sistem pakar diagnosa penyakit demam panas pada balita yang telah dibuat, diharapkan dapat disosialisasikan kepada masyarakat luas agar dapat digunakan sesuai dengan fungsinya 


\section{DAFTAR PUSTAKA}

Arhami, Muhammad, 2005, Konsep Dasar Sistem Pakar, Andi Offset, Yogyakarta

Graham, Robin dan Burns Tony, 2005, Lecture Notes On Dermatologi : Edisi Kedelapan, Jakarta : Erlangga

Jogiyanto, HM, 2005, Analisis \& Desain Sistem Informasi, Andi Offset, Yogyakarta

Kadir, Abdul, 2003, Pengenalan Sistem Informasi, Yogyakarta : Andi

Kadir, Abdul, 2005, Dasar Pemrograman WEB dengan ASP, Yogyakarta : Andi

Kristanto, Andi, 2003. Perancangan Sistem Informasi dan Aplikasinya. Yogyakarta : Gava Media.

Kusrini, 2006, Sistem Pakar, Teori dan Aplikasi, Yogyakarta : Andi

Kusumadewi Sri, 2003, Artificial Intelligence (Teknik dan Aplikasinya), Graha Ilmu, Yogyakarta

Kusmadewi Sri dan Hartati Sri, 2010, Neuro - Fuzzy Integrasi Sistem Fuzzy \& Jaringan Syaraf Edisi 2, Graha Ilmu, Yogyakarta. 